\title{
FAMÍLIAS DESAGREGADAS SOBRE A TERRA RESSEQUIDA: INDÚSTRIA DA SECA E DESLOCAMENTOS FAMILIARES NO NORDESTE DO BRASIL
}

\author{
Marcos Paulo Santa Rosa Matos ${ }^{1}$ \\ Faculdade de Ciências Humanas e Sociais, Brasil
}

http://dx.doi.org/10.5209/rev_NOMA.2012.41773

Resumo: Analisa-se a indústria da seca e da identidade nordestina em sua evolução histórica e em seus efeitos nos arranjos familiares no Nordeste do Brasil. Partindo das dicotomias estiagem/seca e migração/retirância, reflete-se a natureza social dos fenômenos naturalizados nas representações quotidianas, bem como as desigualdades de classe que perpassam toda a sociedade daquela região. A produção cultural/discursiva do Nordeste e da seca é compreendida numa perspectiva de luta político-ideológica pela preservação do poder das elites regionais, frente às mudanças políticas e econômicas dos séculos XIX e XX. Por fim, o discurso da seca é estudado em suas contradições histórico-sociais e simbólicas: os deslocamentos espaciais e referenciais na sociedade nordestina tornam ambíguas suas instituições, e promovem um distanciamento entre discurso e realidade.

Palavras chave: nordeste, seca, miséria, migração, desestruturação familiar

\section{Broken families about parched land: industry of the dry and family shifts in the northeast of Brazil}

\begin{abstract}
It analyzes the industry of dry and of northeast identity in its historical evolution and its effects in familiars arrangements in Northeast Brazil. Starting from the dichotomies drought/dry and migration/retreat, reflects the social nature of naturalized phenomena in everyday representations, as well as the class inequalities that permeate all of society in that region. The cultural/discursive production of the Northeast and of the dry is understood from the perspective of political-ideological struggle for the preservation of the power of regional elites, in the face of political and economic changes of the XIX and XX centuries. Finally, the discourse of the dry is studied in its historical-social and symbolic contradictions: the referential and spatial shifts in northeast society make ambiguous its institutions, and promote a distancing between discourse and reality.
\end{abstract}

Keywords: northeast, dry, misery, migration, family destructuration

\section{Introdução}

A seca é uma realidade ecológico-sócio-política que tem flagelado o ser humano em muitas épocas históricas, e em considerável parte das sociedades, porque normalmente é sinônimo de escassez de trabalho, água e comida. A partir dessa constatação do valor deletério da seca para a dignidade humana e

\footnotetext{
${ }^{1}$ Graduando em Letras e Direito na Faculdade de Ciências Humanas e Sociais, Paripiranga, Bahia, Brasil.mp.srmatos@hotmail.com
} 
a estabilidade das relações familiares e comunitárias, a análise aqui desenvolvida procura identificar as consequências da dinâmica das secas sobre a dinâmica da vida familiar, sobretudo, no tocante à estruturação simbólico-operativa dos vínculos familiares. Para tanto, partirá de uma diagnose da seca enquanto "artefato histórico-cultural", e, por meio da fenomenologia e da simbologia da seca, procurará descrever os deslocamentos espaciais e antropológicos sofridos pelas famílias flageladas.

Parte-se da premissa de que a afirmação da relação íntima entre escassez de água e fome não é tautológica, pois elas não se pressupõem: a carência pluviométrica de uma região pode ser administrada de tal modo a não comprometer a sobrevivência das comunidades locais. A própria seca não pode ser definida apenas a partir da intensidade e frequência das precipitações, mas envolve uma articulação entre fatores naturais e humanos: a estiagem só transforma-se em seca quando a ela se associa o fantasma da inanição.

Logo, a fome não é um fenômeno que decorre exclusivamente da seca, mas esta "apenas agrava a situação da fome, que tem causas mais ligadas às desigualdades sociais do que aos fenômenos climáticos" (Castro, 1980 apud Fischer; Albuquerque, 2002, p. 1). Todavia, como observam Fischer e Albuquerque (2002, p. 1), "O problema da seca não se manifesta no aspecto específico da água, mas especialmente na escassez de alimento, caracterizada como fome endêmica, relacionada à casa e à mulher, que não é pensada pelos idealizadores da política da emergência da seca" ${ }^{2}$.

Assim, a conjugação da seca e da fome, além de causar inúmeros obstáculos à sobrevivência das famílias e das comunidades - "a fome absoluta ameaça intermitentemente o cotidiano dos atingidos pela seca" (Fischer; Albuquerque, 2002, p. 1), causando não só um mal estar físico, mas também psicológico, social e moral -, implica em deslocamentos sociais e espaciais que desorganizam os microssistemas produtivos locais e provocam uma crise na divisão-organização social e regional do trabalho, num processo que "[...] se torna ainda mais perverso com o crescimento desordenado das cidades grandes. Elas cresceram demais porque milhões de famílias vieram do campo em busca de melhores condições de vida" (Dimenstein, 2005, p. 44).

Dito de outro modo: há um intenso êxodo rural porque

"[...] a seca é um fator gerador de desemprego. Em busca da sobrevivência, os desempregados rurais se deslocam para as cidades, agravando seus problemas e alargando a fronteira do desemprego. Isto faz com que o desemprego rural causado pela seca seja, sem dúvida, um problema social sério e recorrente, responsável não só pelo êxodo rural, mas também pelo povoamento desorganizado das zonas urbanas, que não têm estrutura para

\footnotetext{
2 "Fome" e "falta de comida" não estão sendo utilizados, aqui, como sinônimos, uma vez que o conceito de fome envolve uma multiplicidade de significados, justamente por ser um problema crucial no tocante ao indivíduo e à humanidade:

"No passado, o termo se referia à falta de alimento para saciar o apetite, que, no ser humano, é considerado estágio fisiológico ligado à necessidade alimentar. No sentido moderno, fome é a falta de quaisquer dos quarenta ou mais elementos nutritivos indispensáveis à manutenção da saúde. Essa carência ocasiona morte prematura, embora não acarrete, necessariamente, a inanição por falta absoluta de alimento" (Fischer; Albuquerque, 2002, p. 1).
} 
abrigar um contingente tão grande de pessoas (os flagelados da seca). Como conseqüência, observa-se nestas zonas o aumento no número de mendigos, de favelados, doenças e violência." (Khan et al., 2005, p. 258)

O inchamento demográfico das cidades provoca o surgimento de áreas totalmente desprovidas de infraestrutura urbana e sem acesso aos serviços públicos mais básicos. Dessa forma, a escassez e a miséria não apenas se reterritorializam, como também se tornam mais complexas: a migração provoca perdas culturais e familiares irreparáveis, e desagregam os núcleos sociais mais básicos (família e comunidade), unidos por fortes vínculos históricos de natureza afetiva e política, diluindo-os e reordenando-os em novos arranjos sociais, comunidades notadamente artificiais, cuja história e identidade residem no fato de seus integrantes unirem-se para compartilhar o estado de necessidade quase-absoluto em que vivem.

Dimenstein (2005, p. 44) alerta, porém, que "o problema não é o clima. São os governos", tendo em vista que:

"Com irrigação, mais terras seriam cultivadas, exigindo mais empregados. $E$ existem técnicas usadas desde os primórdios da humanidade. Na Espanha ainda funcionam sistemas de irrigação construídos pelos árabes há mais de mil anos. Bem antes disso, os egípcios levavam as águas do rio Nilo para suas lavouras.

O Brasil tem pouco mais de um milhão de hectares irrigados. Cada hectare é do tamanho de um campo de futebol. Um milhão de hectares é muito ou pouco? Quase nada.

O Chile, que tem menos de um décimo do tamanho do Brasil, conta com 1, 2 milhão de hectares irrigados. No México, a irrigação tornou produtiva uma área de seis milhões de hectares. Na Índia, quarenta milhões de hectares recebem água artificialmente e na China, cinquenta milhões.

Há estudos que mostram que as terras semi-áridas da Califórnia, nos Estados Unidos, eram bem mais difíceis de serem tratadas do que as do nosso Nordeste. No entanto, lá existem 4, 5 milhões de hectares irrigados." (Dimenstein, 2005, p. 44)

Esse fenômeno, portanto, é eminentemente problemático, isto é, discutível em sua própria realidade, questionável em sua natureza de "dado dado" ${ }^{3}$, porque a naturalização da penúria disfarça suas razões históricas e obstaculiza a distribuição de responsabilidades ético-políticas. Além do mais, ele torna mais vulneráveis aqueles que, por sua própria condição histórica, são hipossuficientes. Assim, a seca não traz apenas complicações nutricionais e de saúde, mas comprometem a educação e o desenvolvimento, já que "[...] famílias que perdem seus meios de subsistência devido à seca possivelmente não conseguirão manter seus filhos na escola, nem pagar por serviços de saúde" (UNICEF, 2011, p. 42) e aprofundam as desiguldades em todos os níveis (social, racial, sexual, etário, regional, internacional, etc.), porque os mais carentes são também os mais flagelados.

\footnotetext{
${ }^{3} \mathrm{O}$ "dado dado" da antropologia freireana corresponde a uma existência acabada, inexorável, irremediavelmente realizada e sem nenhuma potencialidade de transformação (Freire, 1999, p. 110).
} 


\section{A indústria da seca}

O Nordeste Brasileiro, como toda divisão política e cultural do espaço humano, "é um produto social que deve ser analisado a partir do seu conteúdo material e social, ou seja, como resultado do processo histórico que o cria sobre uma base territorial" (MENEZES; MORAIS, 2002, p. 10). Nessa perspectiva, ele é descrito por Durval M. Albuquerque Jr. (2007; 2011) como uma invenção político-cultural que se firmou a partir dos primeiros anos de governo da República Velha. $O$ discurso da nordestinidade, que define e justifica 0 Nordeste seria, então, constituído, das seguintes categorias:

“i. O discurso da seca e a indústria da seca - após a grande seca de 18771879, o Brasil que só conhecia duas divisões regionais - Norte e Sul - vê a emergência do conceito de Nordeste, criado pelas elites políticas da região, falidas devido à crise de seu sistema de produção agrícola, também atingidas pela seca, para [supostamente] captar recursos do governo federal e sanar os prejuízos advindos dela. [...]

ii. O tradicionalismo - a elite nordestina foi perdendo gradualmente seu poder sobre a política nacional [...]. A cultura dessa região viveu, por isso, um apego ao passado, uma idealização exagerada da tradição e uma resistência ao progresso e ao desenvolvimento, pois viam neles uma ameaça ao poder e uma descaraterização do modo de produção material e imaterial ali praticado.

iii. A religiosidade - o beato e o romeiro marcam também o imaginário nordestino, emoldurados pelo fanatismo religioso. As figuras messiânicas, o devocionismo, a guerra entre os seguidores de Padre Cícero e as tropas de Franco Rabelo, em 1914, a transferência do poder de mudança da história da esfera humana para a divina, solidificaram a imagem de um Nordeste intrinsecamente relacionado a uma mística extremada [...].

iv. A violência - encarnadas pelo coronel e pelo cangaceiro, representantes do poder reacionário e revolucionário da região, respectivamente. [...] essas figuras passaram a definir a identidade nordestina a partir das relações de violência: aquele que manda estabelece seu poder porque tem uma tropa de capangas e não perdoa desobediência e traição; aquele que contesta o poder o faz pela via da ameaça, do roubo, do banditismo; e o homem mediano é pacato, mas um potencial assassino se sua honra for atingida. O nordestino é um pacifista que embainha uma faca na cintura." (Matos, 2011, p. 1)

Assim, o nordestino seria, antes de tudo, um retirante, alguém que estaria fugindo de uma terra-mãe malvada e hostil, um filho rejeitado, incapaz de sobreviver mesmo no seu torrão natal, um flagelado à procura de exílio. Ao mesmo tempo, seria alguém perigosamente esperto e preguiçoso, pois "sugava" parte considerável das verbas governamentais, custeadas pelos moradores de outras regiões, e, em sua maior parte, desviadas pelas elites regionais e locais nordestinas para seus empreendimentos particulares e para suprir suas necessidades individuais.

Para que se possa compreender, todavia, a indústria discursiva da seca, se faz necessário um entendimento mais aprofundado acerca dos conceitos de seca e de retirante, porque são categoriais lógico-culturais, criadas discursivamente para justificar o próprio discurso criador. 


\subsection{A seca}

O fenômeno sócio-político da seca é construído a partir do fenômeno natural da estiagem, cuja ocorrência é periódica e cujos primeiros registros remontam ao início do desbravamento do sertão pelos portugueses. Assim, padres jesuítas como Antônio Pires, Serafim Leite e Fernão Cardim relataram secas nos anos de 1559, 1564, 1587 e 1592 (Menezes; Morais, 2002, p. 30). Contudo, Manuel Correia de Andrade (1986 apud Fischer; Albuquerque, 2002, p. 1) afirma ser de 1534 o primeiro relato de seca no Nordeste.

Consoante Menezes e Morais (2002, pp. 30-49), a periodicidade da estiagem/seca é de 8 a 10 ocorrências por século, e pode prolongar-se por até 5 anos, atingindo toda a região do Polígono das Secas ou parte dela, e provocando uma escassez branda (seca relativa - distribuição inadequada das chuvas durante o ano) ou grave (seca absoluta - a precipitação pluviométrica não é suficiente para atender às necessidades mínimas da população, das lavouras e dos animais) de água. Contudo, a seca anual (o regime de chuvas situa-se entre $100 \mathrm{~mm}$ e $300 \mathrm{~mm}$, prejudicando a lavoura, e reduzindo a alimentação das famílias e dos animais - estes passam a ser a fonte de renda das famílias) e plurianual (a escassez de chuvas estende-se por dois anos ou mais, provoca a mortandade dos animais e prejudica enormemente a renda das famílias) é apenas uma das tipologias possíveis desse fenômeno, que se manifesta também na forma de estação seca anual (período do verão, que dura de seis a oito meses) e seca "verde" (quando o regime da chuva é instável, mantém a cobertura vegetal, mas não é suficiente para o desenvolvimento da lavoura $)^{4}$.

Contudo, embora as estiagens sejam previsíveis, o seu enfrentamento tradicionalmente dá-se através de medidas paliativas e emergenciais. Nesse sentido, Menezes e Morais (2002, pp. 63-64) classificam as ações de intervenção governamental no combate às em três grandes períodos:

i) dos anos 1870 aos anos 1940, época do coronelismo, em que as políticas públicas se resumiam à estratégia de abastecimento de água do semiárido por meio da construção de grandiosas obras de açudagem e infraestrutura. Acerca delas, Khan et al. (2005, p. 246) comentam que

"[...] embora não se possa desprezar sua importância no conhecimento acumulado sobre as condições físicas e climáticas da região ao longo do tempo, jamais foram efetivas no enfrentamento do principal problema decorrente da estiagem prolongada: o da criação de condições de trabalho e, portanto, de geração de fontes de emprego e renda em níveis mínimos e permanentes para a grande massa de pessoas que habitam os sertões nordestinos."

\footnotetext{
${ }^{4}$ Medeiros (1997 apud Khan et al., 2005, pp. 243-244), por sua vez, classifica a seca em dois tipos: a estacional (ocorre anualmente no período de julho a janeiro) e a periódica, que pode se apresentar como seca total, seca parcial ou seca verde e seca hidrológica. A seca total se caracteriza pela impossibilidade de obtenção de produção agrícola e pela ausência quase total de chuvas. A seca verde se dá quando não há produção agrícola, em razão da pouca quantidade de chuvas ou da sua má distribuição. A seca hidrológica, por sua vez, ocorre quando a precipitação anual é inferior à média do ano na região.
} 
ii) dos anos 1950 aos anos 1970, época do desenvolvimento planejado e do enfoque tecnicista e cientificista, em que buscou-se o aproveitamento racional dos recursos hídricos por meio de atividades diversas desenvolvidas por agências como Codevasf (Comissão do Vale do São Francisco, criada em 1948), BNB (Banco do Nordeste, fundado em 1951), SUDENE (Superintendência de Desenvolvimento do Nordeste, instituída em 1959) e GTDN (Grupo de Trabalho para o Desenvolvimento do Nordeste, constituído em 1958). A visão desse período "[...] argumenta que níveis regionais mais elevados de renda, emprego e produção, e uma maior dependência de outras atividades, que não a agrícola, são as melhores defesas contra a seca" e que a estratégia básica de combate à seca "[...] é a de encorajar todas as possibilidades regionais de expansão econômica [...]" (Robock, 1963 apud Khan et al., 2005, p. 247). Contudo, poucos programas de reestruturação econômica obtiveram êxito, e a ocorrência de novas secas periódicas, em 1966, 1970, 1976, 1979-80, 1982-83, 1987, 1993 e 1998-99, provocou a rearticulação dos antigos programas assistenciais;

iii) a partir dos anos 1970, quando foi implantada uma série de programas de combate à seca como Proterra (1971), Polonordeste (1974), Projeto Sertanejo (1976), Prohidro (1979) e Projeto Nordeste (1984) - este incorporou o Polonordeste e se constituiu de três programas da área produtiva (Programa de Apoio ao Pequeno Produtor Rural, Programa de Apoio a Pequenos Negócios não Agrícolas e Programa de Irrigação) e três da área social (Programa de Ações Básicas de Saúde no Meio Rural, Programa Educação no Meio Rural e Programa de Saneamento Básico no Meio Rural) -, que, apesar de inúmeros avanços, não escaparam às moléstias que costumeiramente inviabilizam os programas governamentais na região - a descontinuidade, a fragmentaridade e a corrupção.

Assim, dada a inépcia das soluções propostas pela cultura popular (ancoradas numa consciência ingênua e/ou mágica) ${ }^{5}$ e pelas agências estatais (por sua vez, fundamentadas em uma visão tecnicista e cientificista) ${ }^{6}$, as estiagens levam ao extremo as dificuldades suportadas pelos sertanejos e esse sobrepeso sobre a carga já trazida torna a vida insustentável:

"[...] a falta prolongada de chuvas em um determinado período só assume a dimensão de calamidade pública devido à situação de pobreza em que vivem milhões de pessoas naquela parte do Nordeste brasileiro. A escassez de chuvas no período do inverno ou a má distribuição espacial e/ou temporal das

\footnotetext{
${ }^{5}$ Freire (1967, p. 105) distingue consciência crítica, ingênua e mágica:

"A consciência crítica 'é a representação das coisas e dos fatos como se dão na existência empírica. Nas suas correlações causais e circunstanciais'. 'A consciência ingênua (pelo contrário) se crê superior aos fatos, dominando-os de fora e, por isso, se julga livre para entendê-los conforme melhor Ihe agradar.'

A consciência mágica, por outro lado, não chega a acreditar-se 'superior aos fatos, dominandoos de fora, nem 'se julga livre para entendê-los como melhor Ihe agradar'. Simplesmente os capta, emprestando-lhes um poder superior, que a domina de fora e a que tem, por isso mesmo, de submeter-se com docilidade. É próprio desta consciência o fatalismo, que leva ao cruzamento dos braços, à impossibilidade de fazer algo diante do poder dos fatos, sob os quais fica vencido o homem."

${ }^{6}$ Menezes e Morais (2002, pp. 35-38) classificam e descrevem os enfoques científicos, técnicos e populares dados ao fenômeno da seca distribuindo-os entre as seguintes categorias: tradicionalista-fatalista, tecnicista-hidráulica, ecológica, sociopolítica e meteorológica.
} 
precipitações constituem, tão-somente, elementos desencadeadores de um processo que transforma em indigentes as camadas mais pobres da população da zona semi-árida. Esse quadro não tem sofrido modificações com o passar do tempo. A irregularidade climática ocorre ciclicamente, de forma inexorável, mas as medidas oficiais para enfrentá-la não têm, historicamente, apresentado a consistência e a continuidade que o problema requer. É bem verdade que o enfrentamento dos efeitos calamitosos da seca representa um desafio de enormes proporções e a sua mitigação exige um esforço extraordinário por parte da sociedade brasileira." (Duarte, 2001, p. 437)

As limitações às atividades produtivas, e, por consequência, à sobrevivência possuem uma base natural e um desenvolvimento social: as condições físicoclimáticas são desfavoráveis à atividade agropecuária de alta produtividade e à forte concentração de terras nas mãos de uma oligarquia rural obrigam o sertanejo a desenvolver uma agropecuária de subsistência em que não lhe é permitido apoderar-se do excedente e guardá-lo, como provisões (Duarte, 2001, p. 429). Assim, à estiagem somam-se fatores de natureza social como o uso de processos produtivos exóticos à região, a não-titularidade da terra, as grandes dimensões do latifúndio, a baixa oferta de alimentos, a insuficiência da rede de serviços, a baixa oferta de trabalho e renda, etc., que fazem da seca um problema regional (Khan et al., 2005, p. 243; Duarte, 2001, pp. 437-438).

Dessa forma,

"A justificativa da total inexistência de chuvas tem alimentado, historicamente, o quadro de vulnerabilidade e miséria no Semi-árido. No entanto, análises comparativas com outras regiões semi-áridas do mundo mostram que o Semiárido brasileiro não sofre da falta de água, mas da irregularidade da chuva. Isso faz com que $42 \%$ das crianças e dos adolescentes do Semi-árido não tenham acesso a poço, rede geral ou nascente, o que afeta diariamente sua vida e limita seu desenvolvimento.

[...] [Dada a vulnerabilidades dessas pessoas, constatou-se nos 211 municípios atingidos pela última grande seca, ocorrida entre janeiro e novembro de 1998, que] houve um aumento considerável da exploração sexual infanto-juvenil; elevação do número de crianças e gestantes desnutridas em função da diminuição considerável da produção de alimentos; e intenso processo de fechamento de escolas em função da falta de água." (UNICEF, 2005, p. 4)

Fazendo alusão a essa realidade social catastrófica e desoladora, o discurso da seca esconde a dimensão sociopolítica da seca, de modo especial a práxis social de captura e desvio de recursos assistenciais-emergenciais do governo federal, de aproveitamento da mão-de-obra fácil e barata, de exploração das crianças e adolescentes, de alta de preços, etc. Isso porque o "castigo da seca" não atinge a todos de forma igual, mas aprofunda as desigualdades preexistentes, como afirma a Fundação Joaquim Nabuco (1983 apud Fischer; Albuquerque, 2002, p. 1):

"Considerando que o Nordeste está dividido em três zonas de diferentes aspectos naturais e que possui infra-estrutura dominada pelas oligarquias agrárias, o assédio aos governantes, quando da instalação das políticas sociais dirigidas à região, é marcante. O momento da seca, para os produtores mais abastados, pode significar mais uma oportunidade para aumentar seu poderio e estender seus domínios com o auxílio das políticas sociais, a exemplo do 
crédito financiado a juros baixos, a ser pago no longo do prazo ou a fundo perdido [...]. [Por isso,] Os produtores potencialmente mais resistentes, formados por grandes proprietários ou pertencentes a famílias abastadas, enfrentam os efeitos da seca com menor esforço e sofrimento, principalmente devido à ajuda das políticas sociais."

Assim, o sistema de opressão das épocas de pré-seca aprofunda-se ao máximo nas épocas de seca, mas não deve radicalizar-se ao limite, pois terminaria por inviabilizar a própria vida, pondo em risco a estrutura mesma das relações de opressão. Sem a intervenção de forças externas - ainda que mal direcionadas e mal aplicadas - as relações sociais entrariam numa espécie de colapso irreversível: a morte das populações e a desarticulação das relações sociais. Dessa forma, o "perigo da morte" deveria ser administrado politicamente com cuidado e precisão: a moderação é capaz de sustentar e aprofundar as relações de poder, mas a extenuação da resistência humana pode levar à desestruturação dos sistemas de produção e de poder.

A seca pode, então, ser definida como uma articulação dialética entre estiagem e vulnerabilidade social, isto é, a incapacidade da população para enfrentar o fenômeno climático. Ela se caracteriza não pela simples insuficiência de chuva e água, mas quando, em concorrência com esse fator climático, há "a fome, desaparecimento de espécies de sementes crioulas, a perda de patrimônio, de rebanho, migração, a falta de perspectiva, doenças físicas e mentais e o desamparo" (Costa; Waquil, 2008, p. 6) ${ }^{7}$, dificultando ainda mais a sobrevivência do nordestino, consoante nota Duarte (2001, pp. 432-433):

"A falta de água penaliza os flagelados da seca não apenas por destruir as suas lavouras e reduzir os seus rebanhos, mas também por Ihes tornar a vida ainda mais penosa. [...] Caminhar um ou mais quilômetros uma ou mais vezes ao dia, sob um sol escaldante e suportando o peso do vasilhame com água é uma tarefa que se soma ao quadro de privações por que passam os flagelados da seca."

Economicamente, a seca tem como características:

"[...] além da quebra da expectativa de produção evidenciada com a redução da produção agrícola da região, o imediato acréscimo nos preços dos alimentos básicos e a queda da demanda agregada, bem como a redução no nível de renda e ocupação rural, desdobrando-se sobre os demais setores econômicos, tais como comércio, indústria e serviços, com a conseqüente redução na arrecadação estadual e nas taxas de crescimento do estado ou da região." (Khan et al., 2005, p. 244)

\footnotetext{
${ }^{7}$ Quanto ao conceito de "seca", Costa e Waquil (2008, pp. 5-6) afirmam que "O fenômeno seca é difícil de ser definido por envolver fatores climáticos, geográficos, sociais e econômicos. A dificuldade em lidar com a conceitualização de seca está em suas duas características fundamentais: a insuficiência de chuvas e a calamidade sócio-econômica", assim, ela é um fenômeno eminentemente social, vinculado a um desastre climático. E Khan et al. (2005, pp. 245-246) acrescentam, citando Botelho (2000):

"A seca não deve ser definida apenas como uma falta absoluta de chuvas. A irregularidade na distribuição das chuvas é que define realmente o fenômeno da seca, provocando anormalidade no clima e constituindo-se como fato social de elevada importância. 'Tanto é verdade, que a República da Alemanha, com média pluvial de 690mm, não apresenta o fenômeno da seca, e o Ceará com um índice pluvial médio de 750mm está sujeito a tal fenômeno'."
} 
Logo, há a redução da renda do agricultor, devido à diminuição do volume e de produção e ao comprometimento da qualidade do produto - que se torna menos competitivo -; e a inviabilidade do desenvolvimento de pastagens, que desorganiza toda e economia regional (Khan et al., 2005, p. 252).

À seca, acompanha a pobreza, fenômeno socioeconômico entendido como a supressão das capacidades básicas - e não simplesmente a insuficiência de renda (Sen, 2001 apud Costa; Waquil, 2008, p. 2) -, e provoca a vulnerabilização das populações, isto é, "uma situação que pode fazer com que pessoas não pobres venham a se tornar pobres, ou aquelas que já estejam em estado de pobreza agravem sua situação" (Shaffer, 2001 apud Costa; Waquil, 2008, p. 3). Assim, a vulnerabilização da região sertaneja é consequência de três fatores integrados: as condições ambientais da região, o tipo de atividade econômica desenvolvida e a situação de pobreza generalizada, cuja relação é assim descrita por Duarte (2001, p. 425):

"As secas podem ocorrer sob a forma de drástica diminuição ou de concentração espacial e/ou temporal da precipitação pluviométrica anual. Quando ocorre uma grande seca a produção agrícola se perde, a pecuária é debilitada ou dizimada e as reservas de água de superfície se exaurem. Nessas condições, as camadas mais pobres da população rural tornam-se inteiramente vulneráveis ao fenômeno climático. Historicamente, a sobrevivência daqueles contingentes de pessoas tem dependido, seja das políticas oficiais de socorro, seja do recurso à emigração para outras regiões ou para as áreas urbanas do próprio Nordeste."

A pobreza sertaneja, por sua vez, é explicada a partir de dois elementos produtivos: a posse da terra e as condições de trabalho. A concentração das terras produtivas nas mãos de uma oligarquia rural obriga a maior parte da população a trabalhar em terras periféricas, pouco rentáveis e de dimensão muito limitada, muitas vezes incapazes de prover subsistência familiar. Como consequência, as relações de produção ali estruturadas, muitas vezes, possuem características pré-capitalistas, constituindo diversos sistemas de divisão do trabalho. No entanto, verifica-se em todos eles a relação proprietário-produtor, seja num modo cooperativo (parceria) ou subordinado (emprego), e a desigualdade na partilha das responsabilidades e dos produtos - que sempre beneficiava o dono da terra (Duarte, 2001, p. 430).

Dito de outro modo: as possibilidades de trabalho são muito restritas; em geral, firmam-se sistemas de articulação produtiva entre latifundiários e trabalhadores, sob a forma predominante de arrendamentos de terras ou de contrato de trabalho temporário. No arrendamento, o proprietário da terra requer parte significativa da produção, embora seja do arrendatário a responsabilidade de providenciar todos os meios necessários para desenvolver as atividades agropecuárias; no trabalho temporário, os salários são baixos e há total submissão ao empregador (Duarte, 2001, pp. 426-427; Menezes; Morais, 2002, pp. 53-59).

Para Duarte (2001, p. 427), "Estas relações de trabalho têm importante significação em períodos de seca, já que elas podem ser facilmente desfeitas, liberando os proprietários rurais de manutenção da mão-de-obra em uma conjuntura econômica tão adversa". Desse modo, o trabalho disponível no tempo de seca é, normalmente, degradante e funda-se em uma "mentalidade 
escravocrata de desprezo ao trabalho manual e de exigência de total submissão do trabalhador" (Neves, 2007, p. 95). Por conseguinte, além das privações materiais e psicológicas, a seca aprofunda o empobrecimento das pessoas vitimadas, que se veem obrigadas a vender seus bens materiais, principalmente seus rebanhos, seja para comprar provimentos e escapar à inanição, seja para custear a migração da família (Duarte, 2001, p. 429), como poetiza Patativa do Assaré (1978), em A triste partida: "E vende seu burro I Jumento e o cavalo / Inté mesmo o galo / Vendêro também / Meu Deus, meu Deus / Pois logo aparece / Feliz fazendêro / Por pôco dinhêro / Lhe compra o que tem / Ai, ai, ai, ai".

Essa instabilidade ambiental e social da vida nordestina faz com que "Quanto mais sistemático for o fenômeno [das secas], mais difícil será para as pessoas se reequilibrarem e estas tenderam a ficarem cada vez, a cada nova seca, fragilizadas, vulneráveis e pobres. (Costa; Waquil, 2008, p. 6). Ela impede que se viabilize a solução pensada por Xavier (1989 apud KHAN et al., 2005, p. 245), segundo a qual "o sertanejo deve aguardar a seca com o mesmo espírito de previdência com que o europeu aguarda o inverno" simplesmente porque, ao sertanejo, são negados também os instrumentos de prevenção e proteção contra a hostilidade ecológico-societária dos ambientes em que vivem.

\subsection{O discurso histórico da seca}

Vieira Jr. (2003) analisa a relação entre a seca e a migração de grupos familiares cearenses entre os anos de 1780-1850 e apresenta o testemunho histórico de diversas autoridades que conviveram com o drama desse fenômeno político-sócio-ambiental. Discorrendo acerca da Seca Grande, ocorrida entre nos anos $1792-3$ e registrada pelo Pe. Joaquim José Pereira, afirma:

"A seca e a fome impunham a muitos sertanejos uma morte na míngua, a ausência de uma alimentação regular gerava o desespero onde qualquer coisa poderia servir de comida. Comiam de tudo e estes alimentos por sua qualidade deletérios da saúde e da vida d'aquelles habitadores, produziam nelles inchações disformes, vômitos de sangue extraordinários, dysenterias ferinas, males cutâneos cruéis, marasmos últimos; vindo por este motivo a povoarem as sepulturas dos campos e dos povoados. Na Paraíba foram mencionados atos de antropofagia em diversas localidades. Era muito comum o envenenamento por meio de mucunan, petó, cole, maniçoba e outras plantas tóxicas, que o povo faminto usava como sustento - embora fosse corrente que elas só eram nocivas quando não comidas com rapadura." (Vieira Jr., 2003, p. 2)

A periodicidade e intensidade desse desastre ocuparam o imaginário nordestino desde os mais remotos anos do povoamento. Com o decurso do tempo, o enfrentamento da seca passou a funcionar como uma espécie de fato social total, conceito definido por Mauss (2003) como um fenômeno social em que tudo se mistura, tudo o que constitui a vida social se integra de tal modo que

"[...] exprimem-se, de uma só vez, as mais diversas instituições: religiosas, jurídicas e morais - estas sendo políticas e familiares ao mesmo tempo -; 
econômicas - estas supondo formas particulares da produção e do consumo, ou melhor, do fornecimento e da distribuição -; sem contar os fenômenos estéticos em que resultam esses fatos e os fenômenos morfológicos que essas instituições manifestam." (Mauss, 2003, p. 187)

Por isso, o fenômeno da seca reúne todos os elementos caracterizadores da identidade nordestina: ela própria torna-se metáfora do nordestino, pois o discurso da seca aproxima homem e natureza e define o homem como aquele que

"[...] seria o produto da natureza hostil em que vivia. [...] um homem telúrico, figurando em seu corpo e mente a paisagem desolada e rude em que tinha de viver. [...] um homem-cacto, um homem caatinga, por isso mesmo um ser seco, espinhento, agressivo, inóspito, hostil, pouco acolhedor, sofrido, torturado, de natureza imprevisível." (Matos, 2011, p. 1)

De modo particular, a seca liga-se à religiosidade, conforme relata Vieira (2003, pp. 4-5):

"Em determinadas épocas do ano o coração sertanejo batia mais apertado, seu olhar vagava pelo horizonte, buscando aterrorizados sinais da chegada da seca. Os habitantes dos sertões paraibano, piauiense, potiguar e cearense destinavam parcela de seu tempo à observação do céu: observavam com o maior interesse a barra de Natal e do Anno-Bom, isto é, o modo porque apparece a aurora de cada um desses dias; e, baseados nesse exame, dão o seu juizo a respeito do próximo inverno. O Sette-estrelo, o Carreiro, a Mancha do Sul, o circo da lua, o ocaso do sol, o céu, etc. Tudo era observado pelos moradores dos sertões, e quando vizinhos, parentes e amigos se reuniam, tratavam minuciosamente em seus serões ou palestras à noite, quando se reúnem no alpendre ou copiar da casa, tirando augúrios ou conclusões encontradas.

Todos continuavam olhando para o céu, alguns mais atentos aos corpos celestiais e outros aos desígnios divinos. Nas missas os pensamentos eram elevados às experiências de Santa Luzia; assim como ao partir das hóstias nas missas de Natal e Ano-Bom: se ellas dão um estalido secco, concluem em desfavor do anno; se ao contrario emittem som surdo, apenas perceptível, têm como bom signal de inverno. O calendário continuava avançando e as esperanças de bom inverno se prolongavam até o dia de S. José [...]."

Tamanho valor social e cultural da seca foi logo percebido e explorado pelas elites nordestinas, sobretudo para obter a benevolência das autoridades na negociação de dívidas e concessão de verbas públicas. Desde os primeiros tempos da colonização houve uma

"[...] manipulação imediata dos discursos, que muitas vezes foram gestados para perdão de dívidas, justificar fragilidades administrativas, para ressaltar a força ou sofrimento de determinada família. Assim, não era raro encontrar documentos que se privilegiavam imagens fortes da miséria da seca com o intuito de referendar solicitações quanto ao prazo de dívidas, ou pedir mais apoio das autoridades portuguesas para determinadas vilas ou Capitanias." (Vieira Jr., 2003, p. 7)

Assim, já no ano de 1794, Antonio Gomes de Albuquerque e o Sargento-mor Manuel Francisco de Vasconcelos, arrematantes dos dízimos da vila de Sobral, 
pediram à rainha D. Maria I uma consignação de suas dívidas à Coroa, em virtude da intensidade da seca de 1791-3; em 1801, a Câmara de Vereadores de Icó, ao sul da Capitania do Ceará, ainda queixava-se ao príncipe regente D. João da miséria a que tinham sucumbido (Vieira Jr., 2003, pp. 3-4); em 1803, a Câmara de Vereadores de Fortaleza enviou uma carta ao príncipe Regente relatando as dificuldades atravessadas pela Capitania e o prejuízo sofrido pela produção agrícola e pelas rendas reais. Uma década após a Grande Seca, em 1804, o Governador do Ceará, João Carlos Augusto d'Oeynhauser, enviou ofício ao Secretário de estado e Negócios da Marinha e Ultramar informando da queda da produção e do comércio em decorrência dos anos de penúria.

Nesses discursos, à seca, tomada como um "fato social total", era atribuído um sentido da igualdade absoluta: ela atingiria a todos de modo inexorável e indistinto. Ou seja: "como um castigo que poderia descer do céu ou subir do inferno, a seca era representada como um ponto de intersecção entre pobres e ricos. A morte aproximava esses estamentos sociais, pois cobrava reações insanas na garantia de sobrevivência" (Vieira Jr., 2003, p. 4).

Essa face do discurso elitista da seca, que aproxima proprietários e produtores, no entanto, é profundamente falaciosa: os primeiros possuíam recursos suficientes para resistir à seca sem a vergonha da miséria, e ainda aproveitavam a fragilidade das classes oprimidas para apoderar-se do seu trabalho e dos seus bens. O discurso negligencia as distâncias sociais concretas, afinal, "Os grandes fazendeiros ou comerciantes não experimentavam a seca da mesma maneira que seus escravos, ou da forma com que vivenciavam os pequenos proprietários, embora os aproximassem na fome". (Vieira Jr., 2003, p. 6), sendo que, afirma Duarte (2001, p. 436), havia pelo menos dois fatores que diferenciavam essas classes:

"Primeiro, que aqueles [os grandes agricultores], dispondo de mais sementes, plantaram proporcionalmente mais. Segundo, que os recursos hídricos acima referidos tendem a secar no decorrer de uma estiagem prolongada e, mesmo que isso não ocorra, eles não são suficientes para salvar a agricultura."

Subjaz nessas construções discursivas uma "mentalidade senhorial", em que são demarcadas as posições sociais do senhor e do servo:

"O Sertanejo expressa um ponto de vista que pode ser associado ao que se costuma chamar de "mentalidade senhorial", com sua estreita vinculação ao regime de propriedade da terra, ao controle pessoal da mão-de-obra, à valorização da obediência e da lealdade e à construção de um conjunto de relações sociais marcadas pelo mandonismo, pela afetividade e pela violência. A sensação de uma riqueza duradoura e segura, produzida sob a direção de uma camada de proprietários herdeiros diretos dos colonizadores brancos, parecia configurar a percepção de um mundo rural rico, estável, permanente, imemorial, ancorado nas características da terra e da natureza, que, apesar dos pesares, nunca deixa de oferecer aos que trabalham um punhado de suas riquezas. Há, assim, um vínculo poderoso entre as relações sociais estabelecidas no sertão e as possibilidades oferecidas pela natureza, identificando umas com as outras de tal forma que as rupturas só poderiam ser pensadas em função da quebra de um ciclo natural, o que efetivamente ocorre em 1877, com a seca. Somente após esta data, portanto, o sertão aparece 
como "hostil" ou "inóspito", palco ressequido de uma vida de sofrimentos e resignação." (Neves, 2007, pp. 87-88)

Esse controle senhorial se fundamentava sobre a hipótese fundamental de que a sociedade nordestina era harmônica e colaborativa. Aos proprietários brancos cabia naturalmente o poder social, o alicerce que proporcionava coesão e fortaleza às relações societárias. A seca, por seu turno, seria um perigo para essa sociedade, pois teria a capacidade de desfazer os laços sociais que unem senhores e camponeses, pela destruição da produção e pela migração generalizada; ela desagregaria a sociedade e a moralidade sertanejas, afinal, a sobrevivência é condição sine qua non ao controle das consciências.

Nesse sentido, a figura do retirante é a grande ameaça para a ordem senhorial: o retirante ao ausentar-se, produz também a ausência do senhor, desamarrase, desvencilha-se da ordem moral que estabelece o modo de relação nos sistemas produtivos nordestinos. Nessa ordem, baseada sobre os conceitos de honra, hereditariedade e propriedade privada ${ }^{8}$, o senhor é também juiz: ele decide baseando-se unicamente em seu próprio discernimento e castiga com veemência - aplicando a mesma violência dos bandos de jagunços que percorrem as áreas semi-abandonadas, espalhando medo e terror - aquele que desafia seu poder ou ameaça a paz social - esta, compreendida como sendo decorrente da coerência promovida pelo senhor.

A retirância, por seu turno, transforma todos em vítimas: "Os senhores, incapazes de manter o controle social e político sobre 'seus' dependentes, se enfraquecem social e politicamente; os camponeses, vagando sem senhores pelas estradas ressequidas, degradam-se na luta desesperada pela vida" (Neves, 2007, p. 96).

Assim, o retirante renega toda e qualquer jurisdição e jurisprudência senhorial, ele parte, e, ao menos dessa vez, é o senhor quem deve resignar-se perante a decisão do servo. Essa figura emblemática, que causa horror tanto ao Nordeste quanto ao Sul, estará discursivamente ligado à seca, mas essa também é uma construção arbitrária e ilusória:

"A migração crescente e nordestinos para os grandes centros urbanos do Sul [...] é atribuída e explicada pela ocorrência das secas, marcando todos os migrantes nordestinos com a pecha de retirantes ou flagelados, quando, na verdade, esta vinha apenas agravar as causas mais fundamentais deste processo migratório que eram a concentração de propriedade da terra da região, as péssimas condições de trabalho oferecidas por uma economia em estágio ainda incipiente de capitalização e as modalidades de trabalho ali

\footnotetext{
${ }^{8}$ Para ilustrar essa ordem axiológica da cultura nordestina, Neves (2007) aponta os romances O Sertanejo de José de Alencar e Os Retirantes de José do Patrocínio. Naquele, destaca como valores do caráter sertanejo a "honra pessoal, altivez, gosto pelo trabalho, obediência, lealdade, valorização da terra e da família" (Neves, 2007 p. 97). E completa:

"o respeito à propriedade privada não é apenas um valor educado na moralidade sertaneja, mas uma luta cotidiana em que qualquer transgressão é vista como uma ameaça à ordem senhorial e punida com o maior rigor. O jornalista carioca [José do Patrocínio] observa, a este respeito, que 'o furto de algumas cannas e laranjas verdes tem sido arbitrariamente punido com a morte'. Muitas vezes, após um 'processo summario', o próprio proprietário termina infligindo aos acusados 'o castigo de algumas dúzias de palmatórias e chicotadas ou então a pena de ter a cabeça raspada em cruz'." (Neves, 2007, p. 95).
} 
prevalecentes, que não privilegiavam o assalariamento nem respeitavam as lei trabalhistas [...].

A maior parte desses migrantes vem da zona rural, a maioria não tem o mínimo domínio dos códigos que regem a vida numa grande cidade; seus hábitos, costumes, formas de pensar, de andar, de falar, estão marcados por sua vivência do campo e por sua condição social de homens pobres, analfabetos, submetidos a uma dura rotina de trabalho e a muitas privações, o que reforçará esta imagem, construída pelas própria elites nordestinas, em seus discursos políticos, de que seríamos uma região presa ao passado, uma região que reagia, inclusive, aos padrões modernos da sociedade ocidental." (Albuquerque Jr., 2007, pp. 107; 102)

Essa imagem de retirante será simbolicamente rica e acompanhará a identidade do nordestino até os dias atuais. O retirante, por sua vez, ao ser rotulado e valorado socialmente, não fica inerte e passivo, mas reage: "Inferior e espoliado, a figura do retirante é acompanhado do cabra-macho, uma invenção do próprio migrante para fugir da humilhação insuportável de sua condição e subordinação, que de fato se concretizou em muitos episódios de violência" (Matos, 2011, p. 1).

Contudo, essa dialética hegeliana do poder senhorial reduz-se a uma elaboração épica da sociedade colonial nordestina, caracterizada como boa e harmônica, e supostamente desestruturada pelo fenômeno da seca. Na práxis, a população nordestina sempre foi manobrada para servir de força-motriz nas mais diversas atividades econômicas do país:

"[...] As grandes correntes migratórias se formaram - muitas induzidas pelo governo - tendo como causa a elevada importância econômica que assumiram determinadas atividades em algumas regiões do Brasil. [...]

O Nordeste foi um centro exportador de mão-de-obra desqualificada e barata para o restante do país." (Menezes; Morais, 2002, p. 42)

Inicialmente, as migrações nordestinas ocorriam no interior do próprio Nordeste, em direção aos municípios das chamadas "manchas úmidas" (Menezes; Morais, 2002, p. 31), mas a partir da Seca Grade de 1877-79 iniciaram-se as grandes correntes migratórias, primeiramente tendo como destino as capitais litorâneas do próprio Nordeste (Vieira Jr., 2003, p. 10), como retrata João Cabral de Melo Neto em seu poema Morte e Vida Severina, e depois os diversos pólos econômicos do país:

"[Na seca de 1877,] [...] as famílias sertanejas, esgotadas todas as fontes de recursos, próprios ou distribuídos pela caridade ou pelo governo, deixam suas pequenas cidades ou fazendas para procurar o apoio ou a ajuda do governo na capital da província, [...]. Era um trajeto novo, engendrado em meio às transformações socioeconômicas que se desenrolavam nos anos posteriores a 1850. As rotas tradicionais, em direção às serras, às terras úmidas e às praias, haviam-se fechado, entre outras razões, pela ampliação da agricultura comercial do algodão, exigindo dos camponeses pobres um aprendizado novo sobre as relações de poder em tempos de escassez, quando o Estado passa a assumir muitas funções, antes concentradas nas mãos dos coronéis, dos senhores de terras e das gentes." (Neves, 2007, pp. 91-92)

A exportação de mão-de-obra, por sua vez, é resultado da 
"[...] coincidência da "seca grande" com o aumento da demandada borracha nos países industrializados fez com que o fenômeno climático se transformasse num fator facilitador da migração para a região amazônica. No período de 1877 a 1890 consolidou-se o papel do Ceará como principal fornecedor de mão-deobra para outras áreas." (Menezes; Morais, 2002, p. 31)

Assim, nos séculos $\mathrm{XIX}$ e $\mathrm{XX}$, as correntes migratórias nordestinas acompanharam a demanda laboral do crescimento econômico do país: o clico da borracha no Amazonas (na transição entre o século XIX e o século XX, e entre 1940 e 1945, com a reativação dos seringais), o ciclo do café em São Paulo (a partir de 1930), a construção de Brasília, da Rodovia Transamazônica e da Rodovia Belém-Brasília (entre as décadas de 1950 e 1970), o desenvolvimentismo industrial do Sul e do Sudeste (nas décadas 1960 e 1970, sobretudo em direção a São Paulo e Paraná). O fluxo de migrantes só diminuirá nos anos 1980 e 1990, devido a crises econômicas que reduziram a oferta de postos de trabalho em muitas regiões e à dinamização econômica do próprio Nordeste (Menezes; Morais, 2002, pp. 42-43).

Esses migrantes serão sempre associados à imagética do retirante, uma construção discursiva naturalizada e categorizada na história e na conceituação do Nordeste, tornando-se elemento constitutivo do "discurso da seca", que, por sua vez, ganha unidade regional e estabilidade histórica - isto é, passa a ser afirmado e defendido como um ponto de intersecção entre a pluralidade de sujeitos sociais e comunidades e culturas locais - a partir da seca de 1877-79, devido à desestruturação do sistema de produção e de poder do Nordeste e da produção política, ideológica, cultural e socioeconômica da "indústria da seca". Ele deixa de ser um elemento caracterizador de uma região e de um povo, para tornar-se o centro e a fonte da identidade do nordestino (inventando o próprio conceito de "nordestino"), ou melhor, sua razão de ser.

Nessas construções discursivas, o sertanejo e o nordestino tornam-se entidades relativamente equivalentes, porque "[...] a imagem de nordestino é reduzido à figura do sertanejo, que é a síntese de todas as imagens anteriormente mencionadas, mas assim definida no interior do próprio Nordeste: o sertanejo é o excluído, quando em sua terra natal; o nordestino é o excluído quando está fora do Nordeste." (Matos, 2011, p. 1)

Esse discurso consiste na elaboração mítico-simbólica da "nordestinidade", isto é, do Nordeste como um lugar determinado no cenário nacional em que imperam a seca e a miséria, caracterizando esse espaço físico-humano como uma "região problema", carente de assistência governamental - política e financeira - para que as pessoas que ali vivem não sejam abandonadas à própria sorte, o que equivaleria dizer "à própria morte". Dessa forma,

"A projeção da imagem de "região problema" no cenário nacional possibilitou, e continua possibilitando, a mobilização política de grupos dominantes em defesa de interesses específicos ante as elites de outras regiões do Brasil o no interior da própria região em que estão inseridos. Nesse sentido, a seca tem se revelado, historicamente, como o melhor pano de fundo para se angariar recursos públicos e proveitos eleitoreiros." (Menezes; Morais, 2002, p. 60)

A "indústria da seca", por seu turno, se caracteriza como "um arranjo de certos segmentos das classes dominantes que se beneficiam indevidamente de subsídios e vantagens oferecidos pelo governo" (Menezes; Morais, 2002, p. 60) 
a partir do discurso político da seca. Nessa época, a produção açucareira dos grandes latifundiários nordestinos vê-se completamente prejudicada pela estiagem, e as elites tradicionais - já ameaçadas pela implantação de grandes usinas de açúcar - enfrentam um futuro incerto e pouco promissor. A crise da década de 1870 acelerou a decadência das elites nordestinas e a ocorrência de uma longa estiagem, que se diferenciava das anteriores apenas por sua intensidade, serviu como matéria-prima da indústria da seca, consoante comenta Albuquerque Jr. (2007, pp. 91-92):

"Enquanto a seca matava apenas animais, escravos e homens pobres, ela nunca havia sido considerada um grande problema, nunca havia despertado tanta atenção, seja nos discursos parlamentares, seja nos discursos oficiais, seja na imprensa. Mas esta seca ocorre num momento de crise econômica e de declínio político dos grupos dominantes desta área do país. Ela, pela primeira vez, atinge com intensidade setores médios dos proprietários de terras, com a falência de alguns, a morte ou a necessidade de migração de outros. A própria existência de uma imprensa mais organizada e com capacidade de repercutir o fenômeno em nível nacional, algo que não ocorreu em secas anteriores, dá uma repercussão a esta seca como não fora dada a nenhuma outra anterior, por isso esta se tornou a grande seca, marco em qualquer história das secas que seja elaborada na região ou sobre a região."

A partir desse momento, dá-se a "invenção do Nordeste" ${ }^{9}$, ou seja, a produção da identidade nordestina, no espaço político-econômico nacional, que desde o início está associada à inferioridade, à escassez de recursos e de oportunidade. Resta às antigas elites, a reação por meio do capital intelectual, representado pela nova geração - homens letrados, filhos dos antigos "coronéis" -, por meio da reelaboração discursiva da identidade regional - o regionalismo da geração 1870. O Nordeste começa a ser folcloricamente situado numa época pré-industrial - a era dos engenhos, idade de ouro do Nordeste, anterior à emergência da sociedade liberal, que destronava os ricos e desamparava os pobres -, marcado pela dialética harmoniosa entre a casagrande e a senzala. Diversas manifestações culturais - literatura, teatro, pintura, cinema -, custeadas por ricos e pobres, encarregaram-se de difundir essa imagética em todas as classes sociais e na pluralidade de localidades nordestinas, acompanhando a agenda de eventos religiosos católicos (Albuquerque Jr., 2007, pp. 102-104).

Esse regionalismo oitocentista, cujas obras principais são O Sertanejo (1876) de José de Alencar (1829-1877), O Cabeleira (1876) de Franklin Távora (18421888) e Os Retirantes (1879) de José do Patrocínio (1853-1905), será aprofundado no movimento modernista da década 1930 (Romance de 30), através das obras $A$ bagaceira (1928) de José Américo de Almeida (18871980), Menino de engenho (1932) e Fogo Morto (1943) de José Lins do Rego (1901-1957), O Quinze (1930) de Rachel de Queiroz (1910-2003), São Bernardo (1934) e Vidas Secas (1938) de Graciliano Ramos (1892-1953); havendo, em ambos os movimentos literários, o destaque de autores cearenses, cuja região foi a mais afetada natural e socialmente pela Grande

\footnotetext{
${ }^{9}$ A "invenção do Nordeste" é temática ampla e profundamente abordada por Albuquerque Jr. (2011).
} 
Seca (Albuquerque Jr., 2007, p. 121; Araújo, 2005, p. 1; Rodrigues, 2002, p. $272)^{10}$.

Esses autores dividem-se entre reacionários e revolucionários. Os primeiros, entre os quais estão José Américo de Almeida, José Lins do Rego e Rachel de Queiroz, "filhos da 'elite regional' desterritorializada", fazem uma apologia a um passado romântico e glorioso, de ordem e harmonia para todos (do fausto da casa-grande e da "docilidade" da senzala, na paz e tranquilidade do Império) e escondem as verdadeiras relações de poder - baseadas na opressão e na desigualdade - que nele reinavam (Albuquerque Jr., 2011, p. 47). Os revolucionários, como Jorge Amado, Graciliano Ramos e João Cabral de Melo Neto, por sua vez, produziram um Nordeste ao avesso, denunciando a miséria e injustiça social da região; estes, comentam Menezes e Morais (2002, p. 37), "[...] relacionam relatos e narrativas históricas do acidente climático a uma trama ficcional" e têm "[...] como intenção denunciar os problemas econômicos do Nordeste, o drama dos retirantes e a exploração do povo num sistema social injusto"; contudo, "Estes 'revolucionários' ajudam os 'reacionários' a consagrarem uma dada imagem e um texto da região, que se impõem, até hoje, como verdade; uma visibilidade e uma dizibilidade dos quais poucos, como os tropicalistas, conseguem fugir" (Albuquerque Jr., 2011, p. 47).

Nesse contexto profundamente inventado e descaracterizado, as classes dominantes fulguravam como protetoras da região e da cultura nordestinas, contra o modernismo e os movimentos cosmopolitas, ameaçadores da autenticidade, da pureza e da originalidade das produções culturais nordestinas, expressão mais verdadeira da identidade nacional - por supostas razões históricas e étnicas (Albuquerque Jr., 2007, pp. 104-105).

No entanto,

"[...] esta defesa de uma cultura trazia e traz embutida a defesa de uma dominação, de um espaço de domínio que se via ameaçado pela hegemonia de outras parcelas das classes dominantes do Brasil. O Nordeste, como a maior parte dos espaços regionais, é recortado do todo nacional para servir de trincheira e representar uma dada dominação política, e social que se expressa de maneira territorial. O Nordeste nasce como o último território de domínio que sobrou para as elites agrárias do Norte, que antes dominavam o espaço nacional e agora se viam arrinconadas e reduzidas à dominação sobre apenas uma área do país." (Albuquerque Jr., 2007, p. 105)

Essa passagem de um discurso fragmentário para um discurso metanarrativo acerca do Nordeste e da seca provoca um conflito entre natureza e sociedade, presente e passado: a natureza seria perversa e destruiria a sociedade nordestina perfeita; a seca, mais do que o "pecado original", teria transmudado o Éden nordestino num limbo insuportável. Surgia, assim,

"Uma visão nostálgica sobre um passado de fartura e segurança, identificada ao ponto de vista senhorial, passa, neste momento, a estigmatizar a natureza

10 Outras obras de grande destaque, não pertencentes a esses dois grandes movimentos regionalistas, são: Os Sertões (1902) de Euclides da Cunha (1866-1909), Morte e vida severina (1956) de João Cabral de Melo Neto (1920-1999), Grande Sertão: veredas (1976) de João Guimarães Rosa (1908-1967), Essa terra (1976) de Antônio Torres (1940-) e A hora da estrela (1977) de Clarice Lispector (1920-1977). 
como fonte, simultaneamente, da abundância e da escassez. [...] À idealização da natureza corresponde a idealização das relações sociais. Os trabalhadores "exploram as parcelas de terrenos que lhes são arrendados, por conta própria e independentemente da retribuição dos serviços prestados aos fazendeiros". A repetição do fenômeno da seca, contudo, marca a vida do sertanejo, que é

(...) o Sisipho resignado, sabedor de seu destino cruento, attento ao rumor das tormentas próximas - a dôr deu lhe a faculdade da fortaleza ingenita, transmitida pela hereditariedade ancestral, consagrada no berço, bebida no seio das matronas robustas, mais tarde desenvolvida pelos exemplos viris dos pais." (Neves, 2007, p. 88)

Essa nostalgia produz

"[...] um nordestino deslocado e infeliz, saudoso, eternamente saudoso de sua terra, um sujeito que não assumiu o novo espaço social em que se encontra, que não se abriu à novidade e refugia-se num passado cada vez mais distante. Um nordestino neurótico: vive em função de um possível retorno, mas uma mera utopia que não o ajuda a viver melhor e cada vez mais o oprime." (Matos, 2011, p. 1)

Dessa forma, a fome, a espoliação material, o trabalho degradante e a migração fazem parte do estatuto da nordestinidade que, somados ao fenômeno da estiagem, configuram a seca. No entanto, não é a seca que produz a penúria nordestina, ao contrário, é a miséria que transforma a estiagem em seca, de modo que "Existe de fato uma seca social permanente na vida do trabalhador do campo, constituída pela concentração da terra e do poder econômico e político nas mãos das mesmas e poucas pessoas" (Menezes; Morais, 2002, p. 58).

A seca - ou, antes, seus elementos constituintes - desagregam não apenas os sistemas sociais e produtivos nordestinos, como também a vida e a estrutura familiar. Tornar-se retirante passa a ser a única opção viável para a manutenção da vida - ou o adiamento da morte: é o último recurso para escapar à sorte funesta ou, e essa tem sido a interpretação majoritária, trata-se apenas de uma resignação ao próprio destino - retirar-se seria o cumprimento de uma obrigação existencial, não de uma decisão autêntica.

\section{A indústria da família}

O discurso da seca, essencial na elaboração imagética e identitária da sociedade nordestina, é também pedra fundamental na edificação histórica da estrutura familiar dessa região.

As famílias nordestinas se estruturam em torno das mesmas categorias sociais arquetípicas da sociedade: seca, religiosidade, tradição e violência. Ela é heterossexual e machista, embora a mulher ocupe um lugar privilegiado na promoção da harmonia doméstica e na viabilização e efetivação dos mecanismos de produção e consumo ${ }^{11}$.

${ }^{11}$ Os arquétipos sexuais da família nordestina são estudados com profundidade por Albuquerque Jr. (2003). 


\subsection{Estrutura familiar}

No arranjo familiar sertanejo, homem e mulher têm lugares e papéis fixos, que a tornam uma instituição peculiar no cenário social:

"É composta pôr homens valentes, destemidos, "machos sim senhor", pôr isso não "levam desaforos pra casa". Nunca visualizamos um pai de família ou um filho adulto sentindo dor, temor, medo ou qualquer outro sentimento que demonstre "covardia", pois isto fere a sua masculinidade. São "cabras-dapeste", caracterizados como viris, rijos, fortes, heróis do sertão que honram as calças que vestem, símbolos da masculinidade e da integridade, que mandam e desmandam pelo simples e maravilhoso fato de terem nascidos homens?

Enquanto que as mulheres destas famílias são desenhadas [...] como sinônimo de benevolência e passividade, de silenciosas matronas ou obedientes mulheres que se calam, engolem o choro e as palavras, que gaguejam quando vão pedir ou falar algo aos seus maridos. São mulheres que sentem, mas nem sempre extravasam, que pensam, mas raras vezes falam; que choram em silêncio porque chorar é agredir os ouvidos dos seus senhores. Sendo ao mesmo tempo fortes, guerreiam junto aos homens em meios às macambiras e mandacarus, porém sem deixar de serem consideradas frágeis, que devem ser submissas e obedientes aos seus maridos." (Rodrigues, 2002, p. 272-273)

São figuras simbólicas que compõem a identidade nordestina e a narrativa da seca, produtos de amplos e profundos processos culturais ocorridos durante 0 século XX, de modo particular, "perpassando o universo da historiografia e da sociologia regionais, na literatura popular e na erudita, na música, no teatro, nas declarações públicas das autoridades nordestinas, enfim, nas práticas discursivas e não discursivas" (Rodrigues, 2002, p. 273). Esses discursos são aceitos como intrínsecos à família nordestina, constituída por homens e mulheres fortes e valentes, mais fortes do que a própria seca que os castiga e que provoca a resistência que lhe dá identidade. Numa perspectiva metafórica, a seca é para o nordestino aqui que o fogo representa para o ferro: testa, molda e fortalece. Com isso, a própria calamidade da seca ganha um valor religioso: como o ferreiro manuseia o ferro depois de submetê-lo ao fogo, também Deus testa a fé e a coragem do nordestino impingindo-lhe uma verdadeira provação.

Nesse universo simbólico, o masculino está ligado à animalidade, à brutalidade e à violência:

"[...] o nordestino é estereotipado como macho, como uma figura de atributos notoriamente masculinos, mesmo os seus defeitos (como beber cachaça, maltratar a mulher, se envolver em contendas, disputas, pelejas, de andar com peixeira nos "quartos", se envolver em adultérios etc. Fazem parte de um universo de imagens, símbolos e códigos que definem a masculinidade na sociedade nordestina." (Rodrigues, 2002, p. 273)

O homem é caracterizado como o macho provedor, a que deve se submeter toda a família, ainda que por ele maltratada ou abandonada, tendo em vista que há uma ocorrência histórica relativamente grande de violência contra a mulher e a prole; sua posição fálica faz com que todos os demais membros familiares girem em torno dele, de seus gostos e de seus arbítrios. Contudo, esse arranjo familiar, afirmado discursivamente, é parcialmente verdadeiro: 
muitas famílias ultrapassam e mesmo negam esse estereótipo, havendo uma ocorrência considerável do predomínio do feminino sobre o masculino, havendo famílias onde a mulher assume o perfil de uma verdadeira "guerreira", responsável por unir, formar e dirigir a família - sobretudo, naqueles arranjos domésticos em que o homem, sozinho, não é capaz de prover a subsistência familiar; noutras, ela acumula o papel de masculino e feminino, sendo a única responsável pelo sustento do lar.

Essas posições ganham rigidez e sentido a partir da ocorrência da seca, dito de outro modo: a seca leva ao extremo a especificidade das posições sociais ocupadas por cada integrante da família. Nesse sentido, Fischer e Albuquerque (2002) afirmam que

"[...] no período de escassez de chuvas, as chamadas necessidades aumentam e comprometem a própria sobrevivência da família sertaneja nordestina, especialmente no que se refere ao suprimento alimentar. Ao atingir tal estágio, a necessidade adquire a conotação de fome, que, amenizada pela rede de solidariedade entre os iguais, é novamente considerada pela família do produtor rural do Sertão nordestino como necessidade básica. Esse processo de solidariedade ocorre através da distribuição do pouco alimento que existe na comunidade ou rede de parentesco, e aquele que dispõe de algum quantum de alimento, socorre quem nada tem para cozinhar. Assim, é através desse arranjo que a solidariedade caricatura a fome, dando-lhe novamente a conotação de necessidade, a qual, em sentido simbólico, pode significar muitas coisas juntas."

Essa solidariedade exigida em tempos de seca se estrutura a partir da divisão de trabalho, de poder e de alimento. A realidade da escassez e o perigo da inanição coletiva, que atingem o indivíduo em sua totalidade e a coletividade de maneira indistinta (Castro, 1980 apud Fischer; Albuquerque, 2002, p. 1), não passam pelo crivo do planejamento, mas obedecem a uma administração rigorosa em que "cabe ao elemento feminino enfrentar a difícil tarefa de gerenciar o alimento consumido no cotidiano, enquanto o homem tem a pesada função econômico-social de produzir e distribuir os gêneros alimentícios" (Fischer; Albuquerque, 2002, p. 1).

Dessa forma, às desigualdades econômico-sociais e regionais, soma-se uma desigualdade familiar com base no gênero e no papel social: as necessidades da mulher são negligenciadas frente à do marido e das crianças, enquanto suas responsabilidades são redobradas. Na divisão cotidiana do alimento, a mulher possui o encargo de "calcular a quantidade de gêneros alimentícios que deve ser consumida diariamente na unidade familiar, muitas vezes, delimita também o alimento de cada membro durante a refeição" (Fischer; Albuquerque, 2002, p. 1) $)^{12}$, preparando e distribuindo "pratos feitos" para o esposo e os filhos, que recebem uma maior quantidade de alimento - embora seja, na maior parte das vezes, insuficiente. $\mathrm{E}$

${ }^{12}$ Fischer e Albuquerque (2002, p. 1) comentam, ainda, que essa administração alimentícia constitui um saber popular altamente valorizado e passado de mãe para filha:

"Assim, mesmo desconhecendo o conteúdo de proteínas, vitaminas e sais minerais dos produtos alimentares, a mulher utiliza seu aprendizado sobre o seu preparo, repassado através de gerações, para improvisar arranjos nutricionais durante a seca, embora tenha a consciência de que a refeição não está balanceada em vista da reduzida diversificação e da quantidade dos itens disponíveis". 
"Caso os pequenos não fiquem relativamente satisfeitos, alguém, que geralmente é a mulher, doa a refeição que lhe cabe. O marido é, sobretudo, contemplado nessa distribuição. O fato de ter pouco alimento para servir na hora da refeição, principalmente para as crianças e o marido, é [...] a prova mais dura que [a mulher] enfrenta na seca. "Esta é uma provação que tira o sono, o sossego, o ânimo e até a vontade de viver" [...]." (Fischer; Albuquerque, 2002, p. 1)

Enquanto isso, o homem sofre apenas com o constrangimento de não cumprir suas obrigações - tarefa associada à sua masculinidade e que é cobrada culturalmente pela sociedade e por ele próprio. Ele dificilmente assume sozinho um núcleo familiar, e não acumula o papel feminino e o masculino.

Ante à falta de comida, principalmente no período da seca,

"Enquanto a mulher procura dar vazão a seus impulsos, dividindo seu desespero com todos na família - chora e insulta o marido e encara o problema com determinação, segurança, esperança, e consegue inclusive levantar o ânimo dos familiares -, o homem tende a assumir calado sua fraqueza e, no geral, fica deprimido e frágil. Esse grau de depressão aumenta na medida em que a mulher, diante da falta de comida para servir aos filhos, cobra-lhe a obrigação de dono de casa e, portanto, de mantenedor da família, exigência que ele tende a ler como negação da sua condição de homem. Diante de tal cobrança, o homem, de um modo geral, demonstra sentimento de impotência e apenas tenta se justificar dizendo que "não tenho de onde tirar"... "não encontro pra quem trabalhar"... e devolve o problema para a mulher, dando-lhe mais uma tarefa: a de pensar sobre o que ele deve fazer. Este é um tipo de situação que deixa o homem um tanto desmoralizado diante da família e com a autoestima em baixa." (Fischer; Albuquerque, 2002, p. 1)

Porém, quando já não há mais possibilidade de resistência - nem ânimo para o enfrentamento direto da situação de miséria em que se encontram -, as famílias tomam uma decisão que altera profundamente o rumo do seu quotidiano e mesmo de suas vidas: emigrar, ou melhor, "retirar-se". Esse é um recurso que, embora estratégico, representa a morte simbólica da estrutura familiar: a seca venceu no território dela, embora não tenha destruído a família, obstaculizou-a de tal modo que sua função mais precípua - garantir a sobrevivência de todos, em especial, das crianças - simplesmente não pode ser atingida. A família falhou, e só pode reencontrar seu caminho numa experiência de renascimento, em outro lugar, com outras possibilidades de existência, como compôs Patativa do Assaré (1978):

"Agora pensando / Ele segue ôtra tria / Chamando a famia / Começa a dizer / Meu Deus, meu Deus / Eu vendo meu burro / Meu jegue e o cavalo / Nóis vamo a São Palo / Vivê ou morrê / Ai, ai, ai, ai

Nóis vamo a São Palo / Que a coisa tá feia / Por terras aléia / Nós vamos vagar / Meu Deus, meu Deus / Se o nosso destino / Não for tão mesquinho / Ai pro mesmo cantinho / Nós torna a voltar / Ai, ai, ai, ai

$[\ldots]$

Em um caminhão / Ele joga a famia / Chegou o triste dia / Já vai viajá / Meu Deus, meu Deus / A seca terrívi / Que tudo devora / Ai, Ihe bota pra fora / Da terra natá / Ai, ai, ai, ai" 


\subsection{Os retirantes}

Para o sertanejo, o deslocamento é uma estratégia de sobrevivência, ocorrendo de maneira frequente e comum, embora tenha discursivamente construído como a ultima ratio do pensamento familiar. Isso se dá em virtude da territorialização ${ }^{13}$ simbólica que o discurso da seca impõe à identidade do nordestino.

Apesar de a terra ser considerada seca, árida e hostil, incapaz de fornecer a seus habitantes um sustento - o que contrasta com o numeroso contingente populacional que lá tem vivido e crescido por séculos, e com as possibilidades e potencialidades ecológicas e econômicas pouco exploradas da região (Menezes; Morais, 2002, p. 21) -, o ato de retirar-se dela transforma-a em algo ideal - numa perspectiva romântica da origem - e

"[...] deixá-la é algo que surge por meio de forças externas: a saída da terra é uma verdadeira tragédia, se morrer nela é algo terrível, deixá-la parece ainda mais recheado de horror, mas é também imperativo.

[...] [Há] um corte de cordão umbilical: as coisas deixadas para traz, que ocupavam um lugar "de direito" na vida daquelas pessoas - o que evidencia a naturalização que o nordestino faz de sua vida social e cultural, impedindo-o inclusive de um olhar crítico mais apurado - deixam um vazio que na verdade é ocupado pela idealização do ausente e pela saudade que faz sofrer mais que a fome.

Parece que as pessoas preferiam morrer ali, no seu lugar, no seu berço, no seu lar. Uma só coisa justifica a saída: é preciso garantir a vida aos filhos, no embate entre o amor à terra e o amor à família, vence este último, mas aquele permanece como um peso nos ombros dos que partem: partem os nordestinos, e o Nordeste vai com eles. O terceiro elemento completa o quadro: é preciso trabalhar, se não como trabalhar no Nordeste, então que seja noutro lugar." (Matos, 2011, p. 1) ${ }^{14}$

\footnotetext{
${ }^{13}$ Conceito derivado da noção de território, que

"[...] pode ser relativo tanto a um espaço vivido, quanto a um sistema percebido no seio da qual um sujeito se sente "em casa". O território é sinônimo de apropriação, de subjetivação fechada sobre si mesma. Ele é o conjunto de projetos e representações nos quais vai desembocar, pragmaticamente, toda uma série de comportamentos, de investimentos, nos tempos e nos espaços sociais, culturais, estéticos, cognitivos." (Guattari; Rolnik, 1986, p. 323)

${ }^{14} \mathrm{O}$ "terceiro elemento" a que o autor se refere pertence a uma conjunção básica de três elementos na formação discursiva da nordestinidade:

"terra, família e trabalho. Perceba-se como a noção de terra enquanto 'lugar' confunde-se com o conceito de 'casa', donde advém a idéia de um Nordeste como casa, lugar familiar, espaço primordial de existência e de identidade, que não somente dá nome aos nordestinos, mas sobretudo representa o carinho familiar e vicinal, o Nordeste como um espaço de ser e de sentir." (MATOS, 2011, p. 1)

Completando essa descrição, Neves (2007, p. 97), afirma que os retirantes constroem sua identidade e sua vida a partir da idealização de

"[...] uma 'idade do ouro', figurada em um passado longínquo, quando reinavam a abundância e a paz (ao contrário da experiência 'real' da vida sertaneja, marcada muito mais pela carência permanente e a violência constante). Segundo ele, 'conservavam-se límpidas, em todas as
} 
Inobstante essas construções discursivas, a decisão de emigrar se impõe às famílias:

"[...] quando as esperanças de um bom inverno acabavam a necessidade de se locomover, para não morrer, aparecia; de modo que elles [habitantes do Sertão] por este principio estão sempre no estado de principiarem, porque não tem outro modo de poderem subsistir do que o da criação de seus gados e animaes, e ainda do lanígero e cabrum. Principia a viagem." (Vieira Jr., 2003, p. 7)

Essa decisão se dá em função do próprio modo e produção econômico do Nordeste: "O acesso a terra pode ser um fator de permanência ou de êxodo do meio rural. Além da sua condição quanto à propriedade da terra, a qualidade da mesma é importante para que os agricultores e agricultoras possam garantir suas atividades econômico-produtivas" (Costa; Waquil, 2008, p. 14); a produção agropecuária não resiste à falta de água, e o nordestino não possui meios eficazes de suprir a necessidade de água diante da escassez das chuvas. Contudo, o deslocamento migratório desarticula todo o sistema social da região, já que pode "infligir o despovoamento de fazendas e vilas" (Vieira Jr., 2003, p. 8), se combinado com a diminuição do rebanho, elemento-base do sistema produtivo do semiárido, conforme nota Vieira Jr. (2003, p. 7):

"Juntamente com as terras, os rebanhos constituem o maior patrimônio material das famílias rurais, seja pelo seu valor comercial, seja como fonte permanente de renda através da venda dos seus derivados, seja, ainda, como fonte de complementação alimentar. As perdas dos rebanhos aprofundam ainda mais a condição de pobreza das populações mais vulneráveis ao efeitos da seca. Essas perdas se devem principalmente à venda - a preços aviltantes, naquelas circunstâncias - à morte dos animais, ou ao abate para consumo e venda."

Desse modo, a seca traçou historicamente o destino das famílias sertanejas: ela "significava morte ou deslocamento. Os rebanhos [cearenses] eram conduzidos para outras paragens, como o Piauí, em busca de um melhor pasto. Essa rota de sobrevivência do gado era marcada por queixadas espalhadas nas trilhas do Sertão" (Vieira Jr., 2003, pp. 9-10). A luta pela sobrevivência encontrava, portanto, a migração como caminho inexorável, instituindo-se numa primeira fase histórica o sistema do "seminomadismo familiar" e, num segundo momento - após a seca de 1877 -, a "retirância".

No sistema do seminomandismo, baseado na lógica da solidariedade familiar, os membros da família emigravam juntos, mas "O deslocamento não acontecia de uma única maneira, e sofria a interferência direta do lugar social e das posses do grupo. Outras vezes a variação era em função da parcela da família que se deslocava" (Vieira Jr., 2003, p. 12). Dessa forma, a população pobre "os pequenos proprietários e os trabalhadores sem terra", mais afetada pelas consequências da seca (Duarte, 2001, p. 427) - migrava para o litoral, procurando trabalho e comida, enquanto os proprietários de terra costumavam possuir uma multiplicidade de propriedades para evitar que suas famílias 
fossem apanhadas pela fome no meio das estradas e morressem à míngua; com isso, eles

"[...] tinham um poder de maior resistência diante da seca, haja vista que seus deslocamentos aconteciam entre as suas propriedades e com isso dependiam menos do auxílio alheio. Ter várias terras em regiões diferentes, principalmente nas sedes das vilas e nas proximidades das serras poderia representar uma estratégia de combate à seca. Estratégia essa que era adotada por segmentos sociais mais abastados, onde esses grupos saiam de uma casa para irem para outra, conforme o período do ano ou a intensidade das secas." (Vieira Jr., 2003, p. 12)

As camadas médias da população, por seu turno, refugiavam-se nas casas de parentes, que "Eram locais onde determinados membros do grupo familiar havia se estabelecido, em função de um deslocamento anterior, e que acabava sendo área de refrigério para toda a família" (Vieira Jr., 2003, p. 13).

Outro tipo de deslocamento muito comum no sistema de seminomandismo é o deslocamento parcial da família. Nesse caso o núcleo do arranjo familiar (pai, mãe e filho) é temporariamente desfeito, dividindo-se a família entre os que partiam e os que ficavam.

"Esse tipo de deslocamento era, na maioria das vezes masculino, e fazia parte da vida familiar de várias Capitanias. O homem partia e deixava a mulher com filhos. O que nesses casos poderia acontecer, [...] era o fato desses homens servirem como batedores para a família. Eles se deslocavam sozinhos, e com isso ganhavam facilidade para andarem e não sujeitavam a família às agruras do desconhecido, localizavam áreas que tivessem condições melhores de alimentação e voltavam para apanhar o resto dos familiares." (Vieira Jr., 2003, pp. 14-15)

Mas, com frequência, o homem abandonava o lar, não mais voltando ou voltando quando seus parentes já estavam mortos. Suas esposas, chamadas de "viúvas de marido vivo", costumeiramente, recebiam uma pequena ajuda financeira do esposo migrante, que diminuía gradualmente até cessar. Nesse caso, a honra e a própria vida familiar - e mesmo a vida subjetiva, devido à inanição - eram perdidas: a tragédia da seca, que já havia atingido o modo de produção material e cultural das comunidades, solapava também a vida moral e orgânica dos indivíduos. (Vieira Jr., 2003, pp. 14-15). Acerca disso, Menezes e Morais (2002, pp. 42-43) comentam que

"As viúvas de marido vivo tornaram-se tão numerosas que passaram a ser cadastradas nas frentes de emergência para receber cesta básica. Ainda que eventualmente se unissem a novos companheiros, coube a essas mulheres, enfrentando grandes dificuldades, pois quase nunca possuíam qualquer qualificação profissional, exceto experiência com a pequena agricultura."

Logo, "Não existia um padrão único de deslocamento das famílias sertanejas diante da seca. As estratégias variavam conforme os estamentos sociais e também a circunstância da chegada da escassez de chuvas" (Vieira Jr., 2003, p. 15). Todavia, os diversos tipos de deslocamento provocam uma desestruturação dos arranjos familiares, seja na elaboração simbólica da distribuição e do exercício do poder, seja na articulação e na vivência dos mecanismos de produção, seja na própria manutenção da unidade familiar, 
conforme nota Vieira Jr. (2003, p. 15), ao analisar os efeitos das secas ocorridas entre os anos de 1780 e 1850 no Ceará:

"A seca se estabelecia enquanto componente da formação e reformulação de grupos familiares. Apesar da inconstância de uma única forma de migração, um ponto pode ser afirmado: o deslocamento era a principal estratégia adotada pelas famílias cearenses diante das secas, e isso poderia gestar domicílios provisórios e uma reconstrução dos arranjos familiares, interferindo diretamente no habitar e no sentido da vida familiar."

Ou seja, a seca e o deslocamento interferiam diretamente "nos sentidos e representações dos laços de parentescos" (Vieira Jr., 2003, p. 15), além de submeter as famílias desestruturadas - e, de modo particular, aquelas desterritorializadas - a uma vida desumana, degradante e, muitas vezes, imoral; tema explorado por José do Patrocínio na obra Os Retirantes, em que retrata a vida dos retirantes chegados à cidade do Rio de Janeiro e destaca a infidelidade, a promiscuidade e a prostituição que assolavam as famílias nordestinas.

"O que chama a sua atenção, portanto, mais do que a fome e a miséria das famílias retirantes, mais do que a vulnerabilidade social dos sertanejos, é a degradação dos costumes tradicionais e dos valores morais que, segundo ele, deveriam ser o esteio da própria nacionalidade recentemente constituída e agora ameaçada pela desgraça natural. As causas desta decadência pareciam ser "o abandono da terra natal e a emigração para outros climas, outros costumes, outra educação", conseqüências da seca, que deslocava todos de seus lugares de origem. Os retirantes não só deixavam para trás seu torrão conhecido, mas especialmente largavam seus "costumes simples", sendo "inopinadamente arremessados em uma capital, que absorveu já todos os vícios do mundo". O choque cultural provocaria, segundo o jornalista, a desagregação dos valores tão solidamente estruturados na sociedade "simples" em que viviam, onde as relações sociais "a que estão habituados" se baseiam na "confiança plena" que dispensam uns aos outros." (Neves, 2007, p. 84)

Para o escritor, tamanha calamidade moral advinha do contraste entre o Nordeste rural e o Sul urbano, entre a solidariedade nordestina, fundada sobre a reciprocidade e a dependência das relações pessoais, e a competitividade sulista, decorrente de uma ampla liberdade individual e do desenvolvimento capitalista. Ele chama a atenção para o crescimento assustador da prostituição feminina promovida pelos seus familiares, em troca de comida, abrigo ou acesso aos serviços públicos (Neves, 2007, p. 84; 96).

Logo, o deslocamento espacial dos nordestinos é acompanhado de um deslocamento cultural e moral que desarticula a família, as comunidades e a própria sociedade, porque altera a dinâmica da produção, do poder e dos lugares simbólicos das diversas instâncias psíquico-culturais.

Será esse deslocamento, essa transitividade heraclitiana do nordestino - e suas supostas causas - que irá definir a sua identidade e sua imagem perante a própria nação:

"O Nordeste vira sinônimo de miséria e de fome, e o nordestino, figura regional que vai sendo desenhada a partir da década de vinte, a própria encarnação da 
miséria. O corpo depauperado e andrajoso do retirante, tantas vezes descrito nos discursos parlamentares, nos artigos de jornais, na produção literária e artística de uma elite regional que passa a viver, cada vez mais, da exploração destas imagens, vai se tornar o próprio corpo do habitante da região. A figura do retirante é uma das mais importantes na elaboração de uma forma de ver e de dizer o nordestino." (Albuquerque Jr.; Ceballos, s.d., p. 2)

Analisando a construção da nordestinidade na canção $A$ triste partida, composta por Patativa do Assaré e musicada por Luiz Gonzaga, Matos (2011, p. 1) afirma que:

"As imagens por ele [Luiz Gonzaga] veiculadas são aquelas que fazem do Nordeste um mosaico, recomposto quando a terra natal torna-se distante e o outro, o outro sofredor tão diferente de mim, torna-se igual, conterrâneo, nordestino. O Nordeste de que nos fala Luiz é o nordeste da necessidade, recomposto como uma tentativa de resgate da própria história e da dignidade, uma reinvenção do lugar de origem daqueles para os quais sua nova situação histórico-social é fatalmente ininteligível. O Nordeste de Luiz é a busca de uma feição."

Esse Nordeste ao mesmo tempo ausente e persistente, observado na obra gonzaguense e patativana, é o que circunscreve o nordestino como um retirado - ao mesmo tempo, prótese e enxerto - é alguém que perdeu a feição, a honra, o lar. As relações familiares nordestinas dissolveram-se no vazio da distância: seja a distância entre os componentes do arranjo familiar, seja aquela que se dá entre cada um dos sujeitos sertanejos e suas respectivas idealizações u-tópicas.

\section{Considerações finais}

As estiagens e as migrações sazonais sertanejas são fenômenos costumeiros no Nordeste do Brasil; no entanto, as desigualdades sociais que imperam sobre as relações humanas cotidianas e suas representações transformam essas ocorrências em verdadeiras catástrofes: a partir do substrato natural, são construídas a seca e a retirância.

Por um lado, essas construções político-culturais são profundamente deletérias: desarticulam o poder, degeneram os sistemas produtivos, desterritorializam os sujeitos, desagregam as famílias e tornam inviável a própria vida. Elas trazem a iminência da morte: seja o extermínio físico pela inanição, seja o aniquilamento simbólico pelo desterro.

Por outro lado, tornam-se momentos históricos de visibilidade da dor e do sofrimento daquele povo que possibilitam a organização popular em torno de ações de mobilização e cobrança de medidas de amparo por parte do governo. São ocasiões em que se abre o debate acerca da problemática fenomenológico-vivencial da nordestinidade. Assim, "Em 1877, a catástrofe centrou o tema na consciência nacional; em 1915, o governo se envolve com as conseqüências do fenômeno; em 1958, a seca leva à fundação da SUDENE; em 1998, transpôs os saques da fome do sertanejo para a sala de jantar do Brasil." (Fischer; Albuquerque, 2002, p. 1). O estatuto ontológico da nordestinidade, contudo, permanece discursivamente inalterado, porque é tido 
como sagrado, natural e imutável, sendo, portanto, não-problemático. Nessas ocasiões,

"[...] homens e mulheres adotam práticas de luta, adequadas a cada conjuntura política. Assim, enquanto os proprietários rurais tomam atitudes que lhes proporcionam ganhos que superam suas perdas, os trabalhadores rurais, particularmente os sem terra, redefinem sua forma de ação ao trocarem o tradicional saque realizado em feiras públicas pelo ataque a transportadores de alimentos administrados pelo governo, além de promoverem ocupação do principal órgão de desenvolvimento da região, a SUDENE, para reivindicar uma política de apoio à população atingida pela seca. A mulher exerce, de modo peculiar, pressão mais direta sobre as estâncias estaduais e municipais que estão mais próximas." (Fischer; Albuquerque, 2002, p. 1).$^{15}$

E tudo isso só é possível porque a seca

"[...] propicia benefício, como o da informação, especialmente através do rádio e a da televisão, que, divulgam e denunciam a situação e ação dos trabalhadores, além da profundidade da catástrofe. Também leva à tona o nível de organização política dos mais afetados, através dos sindicatos dos trabalhadores rurais e movimentos sociais que lhe dão visibilidade, a falta de infra-estrutura da região rural, a exemplo da carência de energia elétrica, a fragilidade do nível educacional da população e a sua convivência com problemas típicos de grandes cidades, como a insegurança, a prostituição, o consumo e o tráfico de drogas." (Fischer; Albuquerque, 2002, p. 1)

Assim, ao desarranjar o poder senhorial e destronar o poder fálico - ou pelo menos relativizá-los -, a seca abre espaço para uma nova ordem de valores na sociedade sertaneja, que pode tanto redundar na submissão dos retirantes em novos sistemas de opressão - como a prostituição, o trabalho indigno, etc. - ou na libertação efetiva - embora não-absoluta - desses sujeitos.

Todavia, tal libertação não depende apenas da vontade subjetiva e da desconstrução mítico-arquetípica dos discursos de identidade: ela pressupõe uma transformação objetiva das relações sociais e produtivas que, em grande parte, depende da boa vontade governamental. Mas as iniciativas governamentais, embora consideráveis, são pouco eficazes e não possuem caráter definitivo, somente emergencial ${ }^{16}$.

A falta de eficácia das medidas adotadas decorre, consoante Fischer e Albuquerque (2002, p. 1), da incapacidade governamental de descentralizar e democratizar as decisões político-administrativas. Assim, apesar de diversas políticas sociais recentemente concretizadas no enfrentamento da seca para corrigir distorções conjunturais geradas pelos modelos econômicos nordestinos

\footnotetext{
15 A Superintendência do Desenvolvimento do Nordeste (SUDENE) foi criada no governo Juscelino Kubitscheck, através da Lei $n^{\circ}$. 3.692, de 15 de dezembro de 1959, e fechada em maio de 2001, devido a denúncias de corrupção e clientelismo, sendo reaberta no governo Lula, por ocasião da Lei Complementar nº 125, de 3 de janeiro de 2007.

${ }^{16}$ Nesse sentido, afirma Duarte (2001, p. 438):

"Calcula-se, extra-oficialmente, que somente com as medidas de atenuação dos efeitos da seca de 1998-1999, o setor público brasileiro gastou cerca de R\$ 4 bilhões (US\$ 3,3 bilhões).

De qualquer modo, acredita o autor deste trabalho que as medidas emergenciais ainda se farão necessárias por muito tempo."
} 
tenham alcançado o êxito de estabelecer um "quantum de equidade social e sustentabilidade ambiental", constata-se que

"Algumas medidas são implementadas sem resultado permanente, pois são geradas no jogo das articulações políticas em que se considera a sociedade como espaço que pertence aos outros. Assim, tais medidas são manuseadas e desviadas no caminho da prática, pois os horrores da seca fortificam interesses regionais. [...]

[Dentre elas, destacam-se] As políticas sociais criadas em períodos de seca [, que] são geralmente transformadas em programas de governo, tendo as verbas alocadas, em tese, de acordo com as prioridades da população. Os programas têm sido, por vezes, direcionados a outros projetos como o da educação, da saúde, da água, crédito etc. ou se tornam exclusivos, a exemplo da chamada "frente produtiva," composta por obra hídrica, capacitação e alfabetização dos trabalhadores." (Fischer; Albuquerque, 2002, p. 1)

Contrariamente a esse modelo emergencial-assistencial, baseado na "utilização de carros-pipa para o fornecimento de água, cesta básica e bolsarenda para a população rural", Khan et al. (2005, p. 259) propõem pelo menos três soluções para o problema da seca estrutural e conjuntural no Nordeste:

i) A democratização das decisões políticas acerca dos projetos governamentais de combate à seca - entendida em seu significado social como complexo de problemas estruturais da sociedade nordestina, maximizados durante a ocorrência das estiagens - por meio da "participação efetiva da população (comunidades) na elaboração e implantação de planos e programas, junto às autoridades federais, estaduais e municipais para a realização de empreendimentos que garantam a redução da vulnerabilidade do homem rural" (Khan et al., 2005, p. 17);

ii) A implantação de um sistema de monitoramento e gestão da seca "capaz de produzir informações refinadas, oportunas, adequadas, integradas e confiáveis, nas áreas de meteorologia e recursos hídricos, sinalizando, através da divulgação por meios de largo alcance" (Khan et al., 2005, p. 17) as tendências e os fenômenos climáticos capazes de interferir na dinâmica social e na sobrevivência das populações, notadamente a ocorrência de longa estiagem e o período anual de chuvas;

iii) A estruturação do saneamento básico em toda a região nordeste, dando especial atenção à construção de uma rede de distribuição de água tratada para os núcleos urbanos e de estruturas de captação, tratamento e distribuição de água para as comunidades rurais, bem como instalar dessalinizadores - nas regiões em que tal mecanismo se constituir uma estratégia pertinente -, com "o intuito de melhorar o nível de vida e o grau de satisfação do homem rural, induzindo a sua permanência no local de origem" (Khan et al., 2005, p. 17).

Contudo, essas soluções ainda manifestam-se utópicas, apesar do considerável investimento governamental na região, sobretudo, através do DNOCS (Departamento Nacional de Obras Contra as Secas) e em parceria com instituições voltadas para a convivência com o semiárido como a ASA (Articulação do Semi-Árido). No jogo político de disponibilização e administração de recursos, 
"As políticas sociais destinadas a essa região ainda não proporcionaram uma base estrutural. suficiente para que a população conviva com as secas sem passar pelo tormento da fome, que fragiliza o seu desenvolvimento em todos os aspectos e desmoraliza o indivíduo na sua dignidade." (Fischer; Albuquerque, 2002, p. 1)

Ante essa constatação que, aliás, é apriorística ao próprio procedimento de análise da realidade, este trabalho procurou, através de uma revisão da literatura científica sobre a temática, mostrar as razões histórico-sociais e os efeitos sociais, econômicos e culturais da crise da seca, que afeta a sociedade em sua inteireza, e as famílias, de modo particular.

Buscou, também, mostrar como a desigualdade social se mantém, e mesmo se maximiza, ante a calamidade natural-social: a seca atinge as classes sociais de modos distintos, havendo até uma relativa lucratividade para as classes mais abastadas. Numa perspectiva diacrônica, avaliou o a importância da elaboração discursiva do Nordeste e da seca.

Desse modo, a crítica empreendida - mesmo que de maneira propedêutica e em caráter não-empírico - contribui para uma reavaliação histórica, política e ideológico-discursiva acerca da invenção da nordestinidade e de seu papel na construção da sociedade regional e nacional, na dinâmica simbólicoarquetípica do poder e na estruturação de modelos familiares e relacionais.

No tocante ao deslocamento familiar, ideia-tema do trabalho desenvolvido, a seca mostra-se como fator de agregação e de desagregação: ao definir e - em certos contextos - ao confundir os papéis de masculino e feminino, ela permite a reconstrução das relações simbólicas e dos papeis sociais: a dominação masculina é, ao mesmo tempo, afirmada e desconstruída: a crise natural, que aprofunda a crise social, torna-se motor e acelerador de uma crise familiar profunda.

Ao perder a sua função de provedor familiar, o homem perde também parte do poder e do papel que é relativamente estável nos períodos de bonança. Ao ausentar-se do lar, o mesmo ao abandoná-lo, o homem abre espaço para a formação de novos arranjos familiares, baseados não na verticalidade do poder fálico e viril, mas na horizontalidade, na sensibilidade na afetuosidade das relações maternas e fraternas.

A dinâmica familiar nordestina experimentava, em épocas bastante longínquas, por via da necessidade, as mudanças estruturais que a sociedade brasileira como um todo experimentaria muito tempo depois, a partir da década de 1960, com a revolução sexual, de orientação feminista e, tempos depois, homossexual. Nela, o masculino é, simultaneamente, supervalorizado e dispensável: o masculino migra de uma realidade concreta para uma imagem orbital de providência e proteção, que pode ser assumida também por mulheres.

Mas há também uma desglamourização da figura do macho: as famílias abandonadas veem-no como um traidor, alguém malvado e desumano, incapaz de ser fiel àqueles que mais o amam. Assim, há uma relativa repulsa à potencial liberdade masculina, pois ela esconde "tanto o médico como o monstro": o homem que sai de casa é tanto o que vai vender sua existência 
para dar vida à família como aquele que despreza os seus e parte numa busca egoística da própria subsistência. O masculino torna-se ambíguo.

Apesar de dessacralizada, famílias inteiras sobreviveram, sob a sombra do masculino - idolatrado ou excomungado -, mas muitas vezes sem que ele fosse conhecido - basta pensar na quantidade de famílias governadas pela mulher, e sustentada pelo marido ausente, migrante, ou aqueles governadas e sustentadas apenas por uma figura feminina. Desse modo, os deslocamentos familiares ocorreram em duas direções territoriais: i) espacialmente, num movimento centrífugo, de retirada, de saída da região nordestina; ii) simbolicamente, por meio da saída do homem, que, embora permaneça, muitas vezes, unido afetiva e financeiramente ao lar, é reduzido à figura de autoridade moral e a fonte de sobrevivência, ou que está definitivamente "fora do lar", como um covarde que mancha "o nome e a honra" de sua família, tornando-se, porém, mnemonicamente onipresente. Transitando entre os campos territorial e simbólico, há a quebra do poder senhorial, que, em parte, se restringe a uma dimensão mítico-simbólica ou épico-narrativa, e noutra, se transmuda em novas formas de senhorio, compadrio e vassalagem que se organizam nas relações entre retirantes e seus novos "coronéis", bem como entre os não-retirantes e os antigos coronéis.

Logo, no discurso da identidade nordestina, de matiz romântica, tanto a figura da terra natal quanto do macho provedor tornam-se relativamente distantes e objetivamente vazias: são elaborações discursivas que, alicerçadas num suporte fático, deslocam-se no tempo e no espaço, construindo uma imagética e um modo de ação e interpretação da/na realidade, mas perdendo sua concretude objetal. Na práxis histórica, as famílias que fugiram da seca ou que a ela resistiram se reorganizaram e reordenaram - dialeticamente com as novas forças sociais dominantes - toda a sociedade - ainda que tenham sobrevivido poderosas relações coronelistas, e que a renovação social nem sempre signifique uma melhoria das condições existenciais dos mais pobres: 0 discurso da seca e do Nordeste se impôs a eles para refrear e até obstaculizar o ritmo das mudanças; dito de outro modo: para defender o Eldorado sertanejo dos coronéis e de seus servos e vassalos, embora esse Eldorado servisse apenas aos interesses de uns, em detrimento da vida, da dignidade e da esperança de outros. 


\section{Referências}

(2003) ALBUQUERQUE JR., Durval Muniz. Nordestino: uma invenção do falo (uma história do gênero masculino - Nordeste, 1920/1940). Maceió, Catavento.

(2007) ALBUQUERQUE JR., Durval Muniz. Preconceito de origem geográfica e de lugar: as fronteiras da discórdia. São Paulo, Cortez.

(2011) ALBUQUERQUE JR., Durval Muniz. A invenção do Nordeste e outras artes. 5 ed. São Paulo, Cortez.

(s.d.) ALBUQUERQUE JR., Durval Muniz; CEBALLOS, Viviane Gomes de. Nordestino: a miséria ganha corpo. Disponível em: $<$ http://www.cchla.ufrn.br/ppgh/docentes/durval/artigos/

segunda_remessa/nordestino_miseria_ganha_corpo.pdf>. Acesso em: 20 maio 2011.

(1978) ASSARÉ, Patativa do. Cante lá eu que eu canto cá. Petrópolis, Vozes.

(2008) COSTA, Ana Monteiro; WAQUIL, Paulo Dabdab. "O empobrecimento e a vulnerabilização da população rural em situações de seca: o caso de Santo Cristo/RS". In: ENCONTRO DE ECONOMIA GAÚCHA, 4, 2008, Porto Alegre. Anais. Porto Alegre, EDIPUCRS.

(2005) DIMENSTEIN, Gilberto. O cidadão de papel: a infância, a adolescência e os direitos humanos no Brasil. 21 ed. São Paulo, Ática.

(2001) DUARTE, Renato. "Seca, pobreza e políticas públicas no nordeste do Brasil". In: ZICARDI, Alicia (Comp.). Pobreza, desigualdad social y ciudadanía: los límites de las políticas sociales en América Latina. Buenos Aires, CLACSO. p. 425-440.

(2002) FISCHER, Izaura Rufino; ALBUQUERQUE, Lígia. "A mulher e a emergência da seca no Nordeste do Brasil". Trabalhos para discussão, n. 139, Recife, jul. Disponível em: <http://www.fundaj.gov.br/tpd/139.html>. Acesso em: 20 maio 2011.

(1967) FREIRE, Paulo. Educação com prática da liberdade. Rio de Janeiro, Paz e Terra.

(1999) FREIRE, Paulo. Pedagogia da esperança: um reencontro com a pedagogia do oprimido. 6 ed. Rio de Janeiro, Paz e Terra.

(1996) GUATTARI, Félix; ROLNIK, Sueli. Micropolítica: cartografias do desejo. Petrópolis, Vozes.

(2005) KHAN, Ahmad Saeed et al. "Efeitos da Seca sobre a Produção, a renda e o emprego agrícola na microrregião geográfica de brejo santo e no Estado do Ceará". Revista Econômica do Nordeste, v. 36, n. 2, Fortaleza, p. 242-262.

(2010) MATOS, Marcos Paulo Santa Rosa. "Pós-nacionalidade e ethos universal: o problema da identidade e da governança global". Revista Eletrônica de Direito Internacional, v. 7, Belo Horizonte, jul.-dez., p. 240-274. Disponível em: <http://www.cedin.com.br/revistaeletronica/ volume7/arquivos_pdf/sumario/marcos_matos.pdf>. Acesso em: 20 maio 2011.

(2003) MAUSS, Marcel. "Ensaio sobre a dádiva, forma e razão da troca nas sociedades arcaicas". In: MAUSS, Marcel. Sociologia e antropologia. São Paulo, Cosac Naify. 
(2007) NEVES, Frederico de Castro. "A miséria na literatura: José do Patrocínio e a seca de 1878 no Ceará". Revista Tempo, v. 11, n. 22, Niterói, jan., p. 8097.

(2002) RODRIGUES, Maria da Conceição Alves. "(Sobre)Viventes de secas: a família nordestina na visão do romancista Graciliano Ramos". In: CONGRESSO LUSO-AFRO-BRASILEIRO DE CIÊNCIAS SOCIAIS, 4, 2000, Porto. Actas, v. 2, Porto, p. 271-274.

(2001) UNICEF. Situação Mundial da Infância 2011 - Adolescência: uma fase de oportunidades. Nova Iorque, UNICEF.

(2005) UNICEF. O semi-árido brasileiro e a segurança alimentar e nutricional de crianças e adolescentes. Brasília, UNICEF.

(2003) VIEIRA JR., Antonio Otaviano. "O Açoite da Seca: Família e Migração no Ceará (1780-1850)". Boletim de História Demográfica, a. X, n. 27, São Paulo, jan. 